Images

vol. XVII/no. 26

Poznań 2015

ISSN 1731-45OX

\title{
Memory grids: Forgetting East Berlin in Krass Clement's Photobook Venten på i går. Auf Gestern warten (2012)
}

Photographs help us to grasp the present moment before it disappears into oblivion, while at the same time providing striking evidence of the inescapable process of forgetting.[1]

Aesthetic responses to the disappearance of the Eastern Bloc, the remnants of which still 'haunt' European post-industrial cityscapes, involve artists of different generations and origins, not the least photographers, whose purpose is often to capture and preserve traces of the past before they ultimately disappear.[2] The renowned Danish photographer Krass Clement (b. 1946), who throughout his artistic career has been preoccupied with modernist photography and the tradition of flâneur street photography, has expressed his fascination with the relation between photography and time. In a recent interview, he reflected on the ways "photography chops time",[3] encapsulating elements from the flow of life and transforming them into pictures - "left-over[s] from past reality." [4]

However, Clement's approach exceeds an understanding of photography as a trace of a (past) reality, as his photobook (the twentieth in his oeuvre) with the Danish-German title Venten på i går. Auf Gestern warten [5] (both parts meaning "Waiting for yesterday") demonstrates. Despite the fact that the book focuses on traces of the communist past persisting in the urban tissue of Berlin, it can neither be labelled ostalgic - a play on words: in German 'Ost' means 'East' - denoting nostalgia for the lost GDR (German Democratic Republic),[6] nor

[1] I am grateful to Mette Sandbye, Professor of Photography Studies at the University of Copenhagen, for her valuable comments and suggestions to an early draft of this article.

[2] To name just a few examples: F. Chaubin, CCCP. Cosmic Communist Constructions Photographed, Taschen, Köln 2011; R. Polidori, Zones of Exclusion. Pripyat and Chernobyl, Steidl Books, Göttingen 2003; A. Bartos, Kosmos: A Portrait of the Russian Space Age, with an essay by S. Boym, Princeton Architectural Press, New York 2001. On photography documenting traces of deterioration in urban space, see M. Michałowska, Foto-teksty. Zwiazki fotografii $z$ narracja, Wydawnictwo Naukowe UAM, Poznań 2012, pp. 345-363.

[3]S. Rifbjerg, “'Det var det, jeg så’”, interview with K. Clement, Weekendavisen no. 2, January, 1, 2015, Kul- tur, pp. 1, 8-9 (all translations from the Danish - AEM). [4] H. Belting, An Anthropology of Images. Picture, Medium, Body, translated by T. Dunlab, Princeton University Press, Princeton 2011, p. 146. As Belting emphasizes, "photography can only have this meaning if we are looking for a trace of reality" (p. 146). This meaning is crucial, but not exclusive, to Clement's photographs.

[5] K. Clement, Venten på i går. Auf Gestern warten, Gyldendal, København 2012, 135 pages.

[6] On the phenomenon of 'Ostalgie', see e.g. M.D. Richardson, "A World of Objects. Consumer Culture in Filmic Reconstructions of the GDR", [in:] J. Fisher and B. Prager (eds.), Collapse of the Conventional: German Film and Its Politics at the Turn of the Twenty-First Century, Wayne State University Press, Detroit, MI, USA, 2010. 
documentary. The question of memory here is approached in a far too complex manner to be explained either by means of indexicality or the ostalgia label.[7]

In this article, I will argue that the logic of Venten på $i$ går. Auf Gestern warten unfolds on two intertwined levels: a self-reflective level concerning photography in relation to memory and reality, and the level of the represented (post)GDR spatiotemporal reality. In a subtle and multifaceted manner, Clement's photobook stimulates reflection on memory, perception, and photography. My thesis is that the book epitomizes memory work,[8] and that its guiding principle can be grasped by means of the concept of the grid. I refer here to a notion proposed in 1979 by the American art historian Rosalind Krauss. In her influential article published in the journal October, Krauss describes the grid as a formal rule and a concept emblematic of modernist art, and especially painting. Grids are characterized as anti-mimetic, anti-real, anti-narrative, flat and geometricized; in a composition guided by grids, the real is replaced by the surface; it is not an imitation but an aesthetic decree. The order of the grid is defined by a pure relationship, while its structure is modular and repetitive.[9] In relation to Clement's photobook, the notion of the grid will help us to grasp photography's relation to memory and the perception of reality. I will argue that memory work in the book operates through the mediating vehicle of grids; the grid is, on the one hand, produced through the structure of the book and in the way it organizes the photographs, and, on the other hand, enacted by the very choice and framing of singular motives.

What are the functions of the grid in Clement's photobook? As I will try to demonstrate, not only does it undermine any chronology of the work of memory; it also questions photography as a medium connecting us with the past and the real, exposing the conventional nature of photography itself. The grid separates the viewer from the viewed in a double sense: it is the grid of the present moment of viewing, denoting the 'eye' of the photographer trapped in the filter of previously seen - recognizable - images; second, the grid is used to represent

[7] As Clement said himself: "Although my photographs owe a lot to the documentary tradition I don't consider myself a documentary photographer. In my photographs, I respond to reality, but I am not in thrall to it", see R. Gade, "Halting, Without Halting: Krass Clement's Drum”, [in:] K. Clement, Drum, Errata Editions (Books on Books series), New York 2012 [unpaginated].

[8] 'Memory work' is a term coined by Annette Kuhn to denote "an active practice of remembering which takes an inquiring attitude towards the past and the activity of its (re)construction through memory. Memory work undercuts assumptions about the transparency or the authenticity of what is remembered, taking it not as 'truth' but as evidence of a particular sort: material for interpretation, to be interrogated, mined, for its meanings and its possibilities. Memory work is a conscious and purposeful staging of memory", see A. Kuhn, "A Journey Through Memory", [in:] Memory and Methodology, ed. by S. Radstone, Bloomsbury Academic, Oxford, New York 200o, p. 186.

[9] R. Krauss, "Grids", October, vol. 9 (Summer 1979), pp. 50-64. Krauss uses both terms: grids and the grid interchangeably. Among the modernist artists whose works serve as examples of the grid in Krauss' article are Piet Mondrian, Robert Ryman, and Agnes Martin. 
the screen of both personal memory and cultural imagination, the distinction between which is vague.[10] Hence, it connotes opaqueness rather than transparency, and in this sense denotes a way of forgetting the GDR 'as it was'.

The complexity of Clement's project is inextricably related to and expressed through the power of the photobook - one of the oldest photographic media.[11] Even though, as Clement himself has admitted, he became aware of the "vibrant" tradition of the photobook rather late in life, he has "always regarded the book as an artistic object in its own right." [12] Combining photography with the book enables the artist to embark on more complex projects than simply documenting reality in a collection of images. The photobook has the potential to create a space "which is both imaginary and given 'real' authority by photography." [13] More precisely, what distinguishes the medium from a mere collection of images is the possibility of shaping meanings "by an image's interactions with another, or its place in a group or sequence, or through its dialectical coexistence with text". Importantly, "it must demonstrate intention and coherence in design [...]. The photobook has a 'particular subject - a specific theme' and what matters most is how the images work together: 'the sum, by definition, is greater than the parts."' 14$]$ The organizing principle in the photobook is, as Patrizia Di Bello and Shamoon Zamir have observed, similar to the principle of montage as theorised by Sergei Eisenstein, according to which a combination of two elements engenders a "third something", rather than being a mere sum of the parts. The experimental and subtle use of montage techniques is evident in Clement's books. This, however, should not come as a surprise considering the fact that Clement has a background in film - he graduated with a degree in film directing from the National Film School of Denmark in 1973.[15]

[10] As Annette Kuhn convincingly argues, see: Kuhn, op. cit., pp. 191-92.

[11] The beginnings of the photobook can be dated back to Henry Fox Talbot, the inventor of negative-positive paper photography, and his series of six fascicles Pencil of Nature (1844-46). Since then, "the home of the photograph has been the book as much as the gallery wall. It could even be argued that the book is the first and proper home of the photographic image from which it moved out to take up residence in the fine art gallery and the modern museum in the early twentieth century", Di Bello and Zamir, op. cit., p. 1. [12] Gade, op. cit.

[13] Di Bello and Zamir, op. cit., p. 12.

[14] Ibid., p. 1, 3. The authors quote here Martin Parr and Gerry Badger's The Photobook: A History 1, Phaidon Press, London 2004, p. 7. Other crucial features of the photobook discussed by Di Bello and Zamir include: the active engagement of the viewer/ reader and the fact that the photobook can only function in a direct and private interaction with the reader; not only mental and visual, but also tactile (haptic) engagement is an important dimension of the experience.

[15] Gade, op.cit. The combination of photography and the medium of the book can also be understood as connecting Clement's work with the literary and artistic tradition of reading/perceiving the city as book or as text - a trope that, as Andreas Hyussen observed, "has existed as long as we have had a modern city literature", see A. Huyssen, Present Pasts. Urban Palimpsests and the Politics of Memory, Stanford University Press, Stanford 2003, p. 54. For Clement, conscious of this affiliation, photography is comparable to a narrative literary process. See Rifbjerg, op. cit. On the other hand, the photobook is often explored as a metaphor for the city street, see Di Bello and Zamir, op. cit., p. 16 (n. 25). 
Indeed, Clement's book reveals itself in the process of reading (or rather, looking) as not simply a collection of pictures - even though the quality of the single image is undeniable - but as a comprehensive project with an elaborate narration, within which the images - and the sparse text - enter into multiple relations both with each other and with the outer reality. The book is distinguished by a textual minimalism, the verbal component being limited to the title (the bilinguality of which should not be neglected) and a white page with three Danish words in capital letters, following a six-picture long visual prologue: ERINDRING, FORESTILLING, VIRKELIGHED. Remembrance (or memory, recollection), image (idea), reality. Additionally, the numerous words and (fragments of) sentences appearing within the frames, including street names, advertising slogans, commemorative plaques on monuments etc., can be regarded as a part of the image-text interaction, so crucial (though not essential) to the medium of the photobook.[16]

Another dimension intrinsic to the photobook worth mentioning in the context of Clement's work is what the Danish photography scholar Mette Sandbye calls "la longuedurée" - the possibility of long-term immersion in one theme, which becomes stored for future generations. [17] In other words, the question of memory is inherent to the photobook. This medium-specific feature translates to the level of the theme: as Di Bello and Zamir emphasize, photobooks are often concerned with "the relations between place, history and nationhood [...] places which have become weighed with cultural memory and myth [...] a concern with the relationship of place and memory". The photobook can be understood as "a vehicle for memorializing this relationship." [18]

Venten på $i$ går consists of photographs both from the GDR period and the early twenty-first century. The strategy of compiling photographs taken over a long timespan is not unusual in Clement's work. The book stages and recontextualizes old and new photographs, producing multi-layered cross-references and "a sense of synchrony, as if remembered events are somehow pulled out of a linear time-frame, or refuse to be anchored in real historical time." [19] Such a way of organising photographic images should be perceived as a staging of memory work, [20] rather than an attempt at constructing a linear and coherent narrative. It is striking that the book provides no information about when and where the pictures were taken. In consequence, the distinction between old and new photographs is vague; an apparently obvious marker seems to be black-and-white versus colour, but we cannot be

[16] See Di Bello and Zamir, op. cit., p. 4. The bilingual title and the three Danish words included in the book mark the cultural position of an observer from outside.

[17] In her press review of two Danish photobooks, Sandbye compares the ephemeral realm of newspaper photography with the medium of the photobook. M. Sandbye, "Frie og ufrie mænd", Weekendavisen no. 29, July, 18, 2014, Kultur, p. 7. Clement himself observes that "the good thing about photobooks is that you can always return to them. It is something completely different than the use of photos in the daily press or as illustrations", see Rifbjerg, op. cit., p. 9.

[18] Di Bello and Zamir, op.cit., pp. 6-7.

[19] As Annette Kuhn writes about 'memory texts', see Kuhn, op. cit., p. 190.

[20] As theorised by Kuhn, see note 8 . 
entirely sure that all the black-and-white pictures are old and all the colour photographs recent. Motives typical of the GDR period, however, appear most frequently in the black-and-white pictures: Trabant cars, fashion typical of the GDR, no-longer-existing street names, or a train car with DR (Deutsche Reichsbahn) on the side. Some pictures can easily be dated as recent due to dates visible on advertising posters (2006, 2009), the presence of modern trams and cars, and relatively new or renovated buildings. While the majority of the photos were taken in areas of (the former) East Berlin, some depict (the former) West Berlin; others could be located anywhere in the provinces of the (former) East Germany.[21] It is difficult both to discern the West from the East, and contemporary pictures from old ones.

Clement has offered a thought-provoking remark about the way he arranges pictures in his books: it is crucial for him that the present moment of viewing be emphasized, even if some pictures are several decades old. The artist points out that this has to do with the way we remember things; the past is typically remembered vaguely and appears milder in relation to the present, even though it might have been different in reality.[22] In other words, we look not only at images, but also with images in the sense that our perception is embedded in the present moment of viewing and filtered through the images we store in and transform through our memory.

Clement's understanding of photography and its relation to the past brings to mind, and can be helpfully grasped with, the French philosopher Henri Bergson's concept of perception and memory, articulated in his book Matter and Memory (1896). According to Bergson, "Perception is never a mere contact of the mind with the object present; it is impregnated with memory-images which complete it as they interpret it." Bergson distinguishes between pure memory, memory-image, and perception, emphasizing that "none of them in fact, occurs apart from the others." [23] Perception cannot be separated from memory, just like the present moment cannot be separated from the past, or from being oriented towards the future: “my present' has one foot in my past and another in my future.” [24]

[21] Photographs on the pages 94-95, for instance, were taken in Halle near Leipzig. Photograph on p. 83 was taken in Hamburg; photographs on pages 120-121, 126-127 in Schöneberg, a borough which belonged to the American Sector in West Berlin. Thus, the (post)communist condition is not limited to the former East Berlin/GDR but encompasses the whole area.

[22] Reflecting upon his use of the medium of the photobook in an interview with Synne Rifbjerg, Clement states that he consciously employs the time-related possibilities it provides. Commenting on Bag Saga blok (København 2014), he emphasizes that the order of the pictures was arranged very carefully and relates to the way we remember things: "The way the old pictures are combined with the new is highly deliberate. Pictures showing trams appear in the beginning of the book, and when you reach the middle parts, the book becomes tougher. This is not just because trams disappear; so does the mildness. This is very conscious, because we also remember the past more mildly compared to the present in which we are, even if [the past] was not mild", see Rifbjerg, op. cit., p. 9.

[23] H. Bergson, Matter and Memory, trans.

N.M. Paul and W. Scott Palmer, MIT Press, New York 1991, p. 133.

[24] Ibid., p. 138. 
While discussing the process of recalling the past, Bergson compared it to taking a picture with a camera:

Whenever we are trying to recover a recollection, to call up some period of our history, we become conscious of an act sui generis by which we detach ourselves from the present in order to replace ourselves, first, in the past in general, then, in a certain region of the past - a work of adjustment, something like the focusing of a camera.[25]

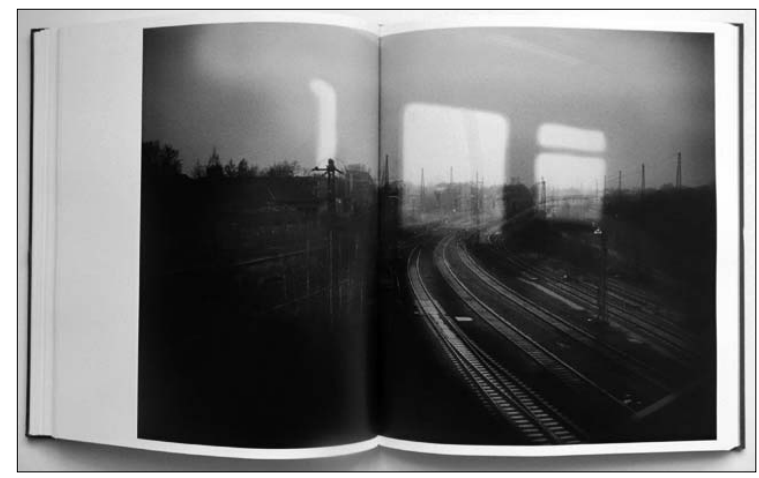

Fig. 1 [colour]

Memory, image, grids

[25] Ibid., pp. 133-134.
Krass Clement indeed focuses his camera on the past, and, more precisely, on what could be called the present past. First, he consequently traces remnants of the GDR in the present tissue of the city. Second, he constantly reminds us about our immersion in the present moment of viewing, due to which seeing the past 'as it was' is impossible. This is visualized through strategies such as mixing old pictures with new, colour with black-and-white as well as by emphasizing the camera's point of view and by numerous shots through windowpanes and other surfaces reflecting things [Fig. 1]. The suspension of the present moment of viewing between the past and the future, discussed by Bergson, is implied by the title of Clement's book: whereas "Waiting" is a present continuous form, semantically the verb denotes an activity oriented towards the future; "yesterday", in turn, refers to the past. This short sentence - Waiting for yesterday - at the same time expresses a rule according to which many of the pictures, both individually and in relation to one another, are organized: a rule that can be called a U-turn, a strategy of reversing directions oriented towards the 'future' - be it the 'future' implied by the direction used to read the book (left-to-right), a path running from left-to-right, or a composition emphasizing directions leading forward. Thus, Clement's perception of Berlin reveals itself to be determined by an (in)visible principle. This principle can be elaborated on by means of the concept of the grid.

A few years before Clement took his most recent pictures of Berlin included in Venten på i går. Auf Gestern warten, the German-American scholar Andreas Huyssen wrote about the German capital in his book Present Pasts as follows:

The city is obsessed with architectural and planning issues, a debate that functions like a prism refracting the pitfalls of urban development at this turn of the century. All of this in the midst of a government- and corporation-run building boom of truly monumental proportions. Nothing less is the goal than to create the capital of the twenty-first century, but this vision finds itself persistently haunted by the past.[26]

Even though Berlin can be viewed as a palimpsest of many "haunting" historical layers, Clement consistently focuses on the GDR layer. The 
newest capitalist layer, of which Huyssen writes, is present only as an absence. Clement's works are often described as nostalgic or melancholic. Indeed, the emotional impact in Venten på $i$ gå is slightly nostalgic, but this nostalgia is at the same time exposed as only one possibility for seeing/remembering the past. The pictures of places, buildings and people avoid glorifying the lost material culture of the GDR. What we see are marginal, anonymous places, dilapidated remnants, grey blocks of flats and buildings which have lost their original functions; we see brothels, empty GDR-style interiors, street signs, old-fashioned looking people, bodies formed by different times.[27]

As mentioned earlier, no comments accompany the pictures apart from a page with the words "remembrance, image, reality". The picture on the following page depicts a huge empty billboard behind barbed wire, with green surroundings in the background, and a strip of path in the foreground, all in a horizontally arranged, frontal, geometrically well-balanced composition [Fig. 2]. The surface of the billboard is the main visual accent in the picture. Its space seems to be waiting to be filled with letters or images, such as posters, ad-

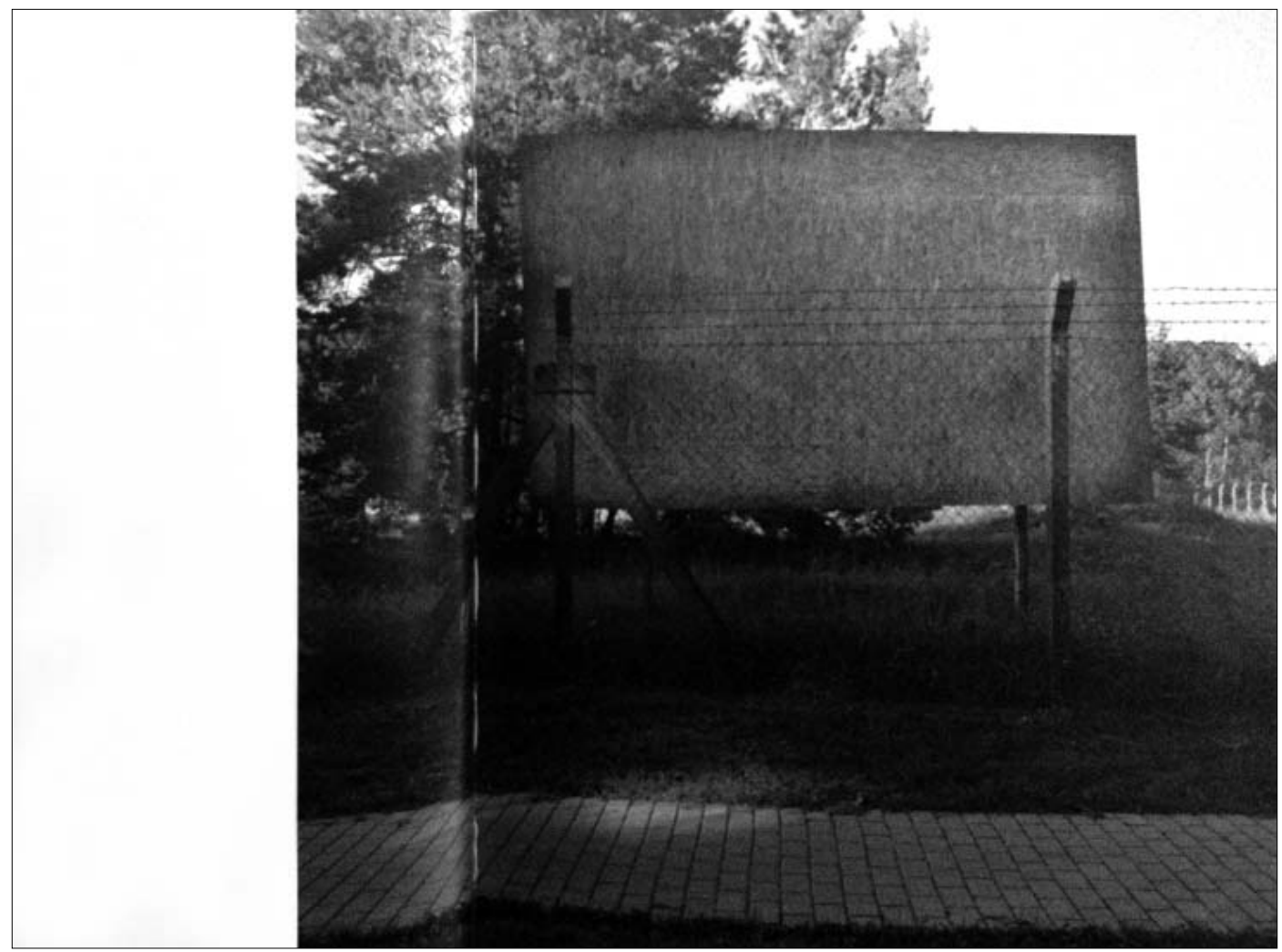

Fig. 2 [colour]

[27] However, it is worth noticing that the b\&w pictures show smiling and happy people in close-ups and interactions with each other, often lit by strong sunlight. This might give an impression of a nostalgic vision of the past as 'better' than today. 
vertisements or "sozialistischen Slogans" [socialist slogans].[28] It is as if the base of any potential image was laid bare, the flatness and materiality of the structure uncovered. At the same time, the huge empty billboard is like a memory of something no longer existing an empty screen.[29] Its large surface obstructs the view. The barbed wire intersecting the lower part in a grid-like pattern can itself serve as a potential surface for projections, most probably unpleasant ones. It is also, at the same time, an abstract structure 'filtering' the dominant element of the picture.

This image is emblematic of the book: first of all, a screen for potential projections obstructs the view of the depicted reality - here, the landscape unfolding behind it; second, the screen (billboard) is part of this reality itself; third, all of these things are perceived through a fence that blocks direct entrance into the represented world, as if manifesting its "will to silence".[30] This image illustrates the way of looking at Berlin and Germany in the book - through the medium of pre-existing grids, found on the spot [Fig. 3], while at the same time it epitomizes the rule of the grid.

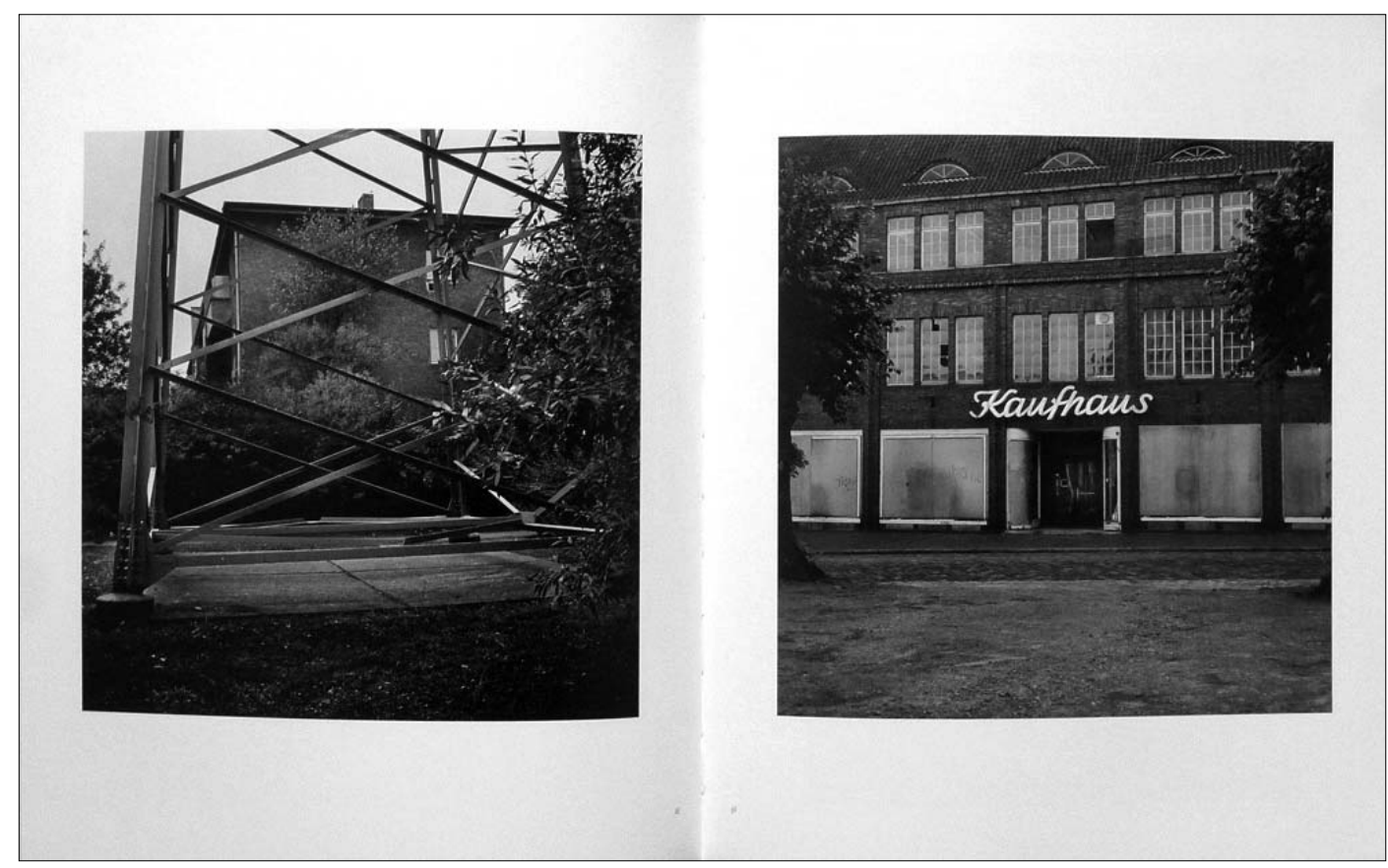

Fig. 3, 3a [colour]

[28] As H. Lohss put it, see http://www.hermannlohss.de/buch-der-woche/venten-på-i-går-aufgestern-warten (accessed: January 18, 2015).

[29] The similarity of the billboard to a screen reminds of Marc Augés words: "all our remembrances [...] are 'screens', not in the sense that they would conceal older memories, but in the sense that they 'serve as a screen' to 'traces' they both conceal and contain at one and the same time", M. Augé, Oblivion, trans. by M. de Jager, University of Minnesota Press, Minneapolis, London 2004, pp. 22-3.

[30] Krauss, op. cit., p. 50. 
Rosalind Krauss devotes a long part of her article to the relation between the grid and reality. Importantly, the grid separates the perceptual screen from the real world. However, its structure is bivalent: like window bars, the grid is both opaque and transparent. This bivalence allows us to read grids in two opposite ways: as a continuation of the outer world and/or as fully autotelic world. Krauss writes:

Logically speaking, the grid extends, in all directions, to infinity. [...] By virtue of a grid, the given work of art is presented as a mere fragment, a tiny piece arbitrarily cropped from an infinitely larger fabric [...] of a world beyond the frame.

At the same time,

The grid is [...] a re-presentation of everything that separates the work of art from the world, from ambient space and from other objects. [...] It is a mode of repetition, the content of which is the conventional nature of art itself.[31]

How can we translate this abstract modernist term to photography and the medium of the photobook? In the case of Venten på $i$ går, both readings indicated by Krauss are not only possible but also necessary and complementary. The real world is an important dimension not least due to the photographic medium's capacity to register real objects, even though photographic images are "far from being transparent renderings of a pre-existing reality." [32] Just as the empty billboard sticks out above the barbed wire, and the green surroundings expand beyond the fence - the real, with documentary intensity, is present in Clement's photographs. Moreover, the grid which guides Clement's looking at Berlin is of a very particular kind and therefore not entirely fitting in Krauss' considerations: it is - as I will try and show - a 'GDR grid', in itself historical and thus not universal, stimulating the viewers' memory. Even though Clement abstracts the motives through angles and framing, the historicity of the act of seeing becomes exposed, not least due to the emotional impact induced by acts of recognition, prompting an ostalgic gaze, at which Clements hints but does not pursue. In the context of his photobook, the grid is not only a formal rule but also a metaphor for memory and perception: the opaqueness it produces - while at the same time being a part of the reality - exposes the opaqueness of our perception and the fact that it is always embedded in the present moment of viewing. As the German art historian Hans Belting somewhat pessimistically put it, "It is useless to direct the camera at the world: there are no images out there. We make (or have) them always and ever only within ourselves." [33] In Clement's book, this opaqueness is additionally enhanced by a pronounced physicality and tactile experience, due to which the photographs are "no longer invisible windows through which we can see our cultural Others or [...] cities we may or may not have visited, but objects of an opaque materiality." [34]

[31] Ibid., pp. 6o-61. Original emphasis.

[32] Kuhn, op. cit., p. 183.

[33] Belting, op. cit., p. 147.
[34] Di Bello and Zamir, op. cit., pp. 12-13. Venten på $i g a ̊ r$ is in hardcover, the pages are sewed together and elegantly bound, the spin covered with a red cloth, the 


\section{'GDR grids'} as separation from the world
The idea of 'GDR grids' - understood as a formal strategy - turns up already in the prologue of the book, consisting of six colour pictures. In one of them, we see the wide, outer wall of a typical East German Plattenbau, [35] with horizontal rows of balconies occupying a large part of the visual field and framed with a vertical wall strip on the left, marking our point of view [Fig. 4]. We can ask along with Krauss: does this picture refer to an outer reality or is it a self-contained image on the verge of abstraction? The perceptual screen is definitely separated here from the real world, but at the same time, it is embedded in it, as is the body of the viewer. Nevertheless, the beholder becomes conscious of the abstracting and mediated act of perception. The picture on the next page only confirms this impression [Fig. 5]. The grid, appearing here in various forms (the bars of a fence, windows in the background, ceiling beams), frames a poster with a huge human eye 'looking' directly into the camera. This image might suggest that when taking a picture, we photograph our own eye - our way of seeing - and not reality 'as it is'. It is worth noticing, however, that the eye in the poster is not a reflection of the photographer's eye but an image of an eye. The

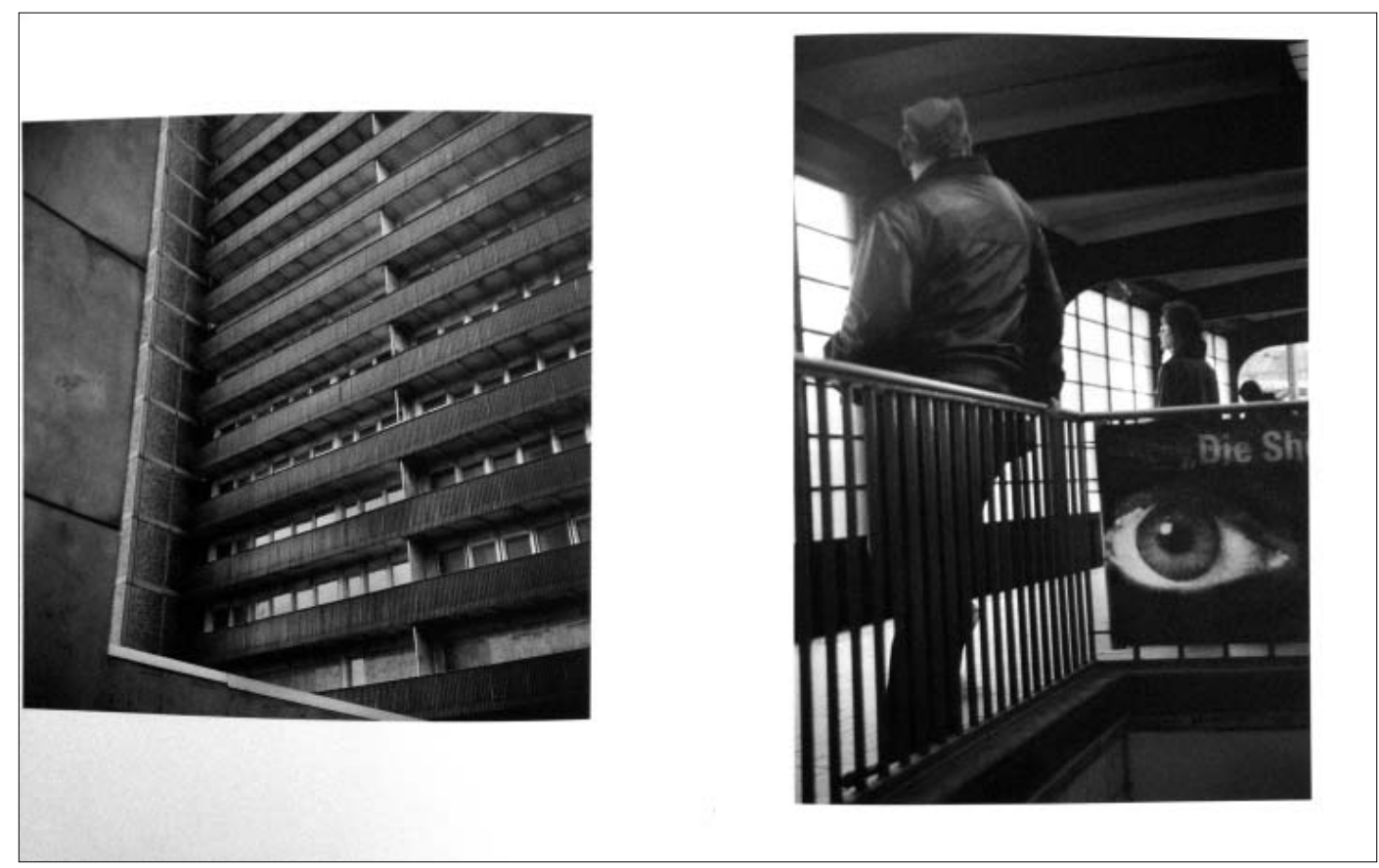

Fig. 4 [colour], 5 [colour]

tactile quality of which is different from the rest of the cover. As Di Bello and Zamir insist, the experience of the photobook "must be grasped not just in its mental but also in its sensuous and haptic dimensions", ibid., p. 12.
[35] 'Plattenbau' is "a building whose structure is constructed of large, prefabricated concrete slabs. The word is a compound of Platte (in this context: panel) and Bau (building)", see http://en.wikipedia.org/wiki/ Plattenbau (accessed: January 28, 2015). 


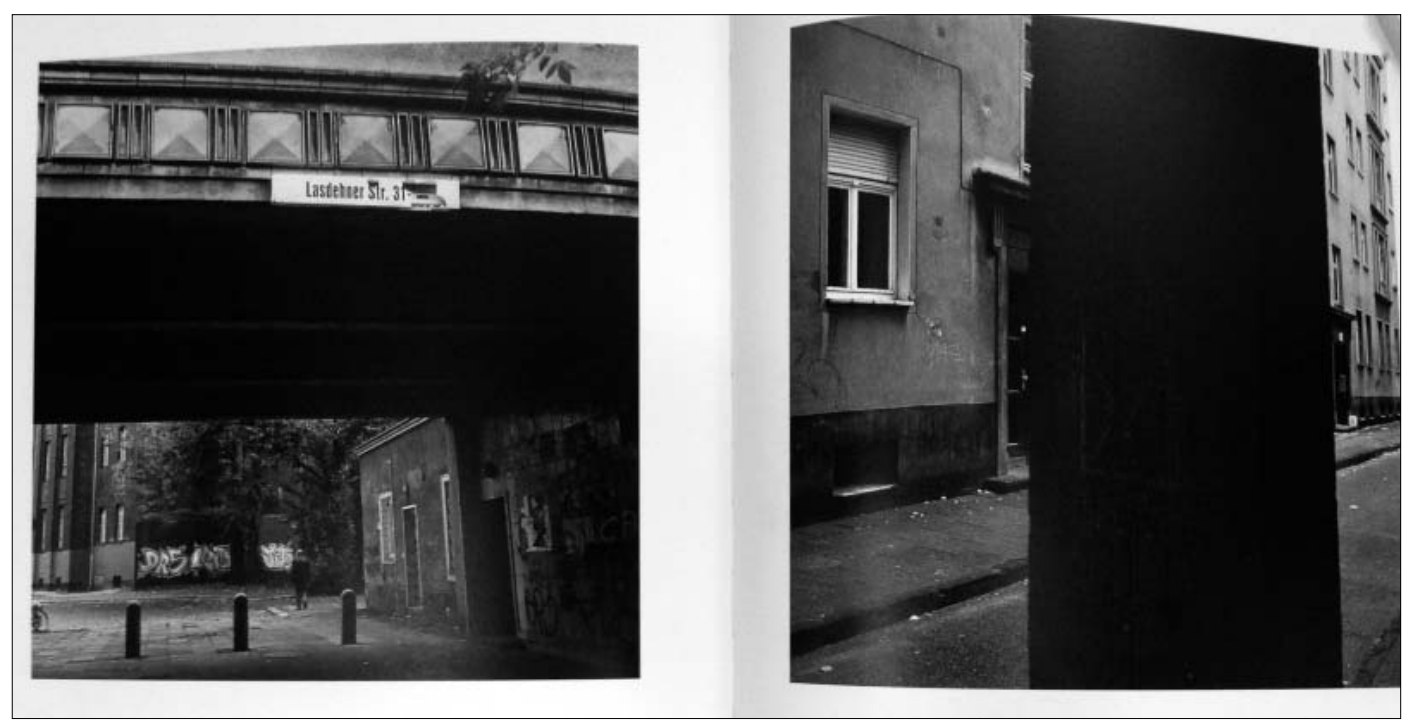

Danish photographer seems to understand the photographic image as a grid through/with which we perceive the world, "a medium that we Fig. 6-7 interpose between ourselves and the world",[36] or memory-image, to use Bergson's term.

The 'GDR grids' are here a filter through which Berlin is perceived. First of all, the fact that the viewer recognizes the GDR layer, even though there are no descriptions, attests to the fact that the pictures remind us of images previously seen. Also, because in many pictures vertical surfaces are emphasized, the effect of the grid is created on the level of the book's structure: the vertical elements intersect with the horizontal direction of the book's reading [Fig. 6-7]. Moreover, the grid is produced through the interweaving of black-and-white and colour photographs, which are perceived through the 'grid' of each other. The juxtaposition of colour and black-and-white photos challenges our perceptual confidence: do we perceive the colour photographs through the grid of the black-and-white - or the other way round? Are the colour pictures contemporary and the black-and-white old? The memory work performed here bypasses linearity and chronology, while the view of photography as a medium connecting us with the past and the real becomes questioned. Sometimes, it is directly indicated that there is no way out of the grid - as in the picture where we explicitly see grids on grids [Fig. 8].

As Belting has noted, both individual and cultural memory have their technical bodies in the institutionalized memory of archives and cameras. Where do these images - the screens of barbed wires and communist remnants through the grid of which Berlin is perceived come from? To answer this question, let us take a look at another crucial feature of the book. As we remember, the grid according to Krauss is

[36] Belting, op. cit. 


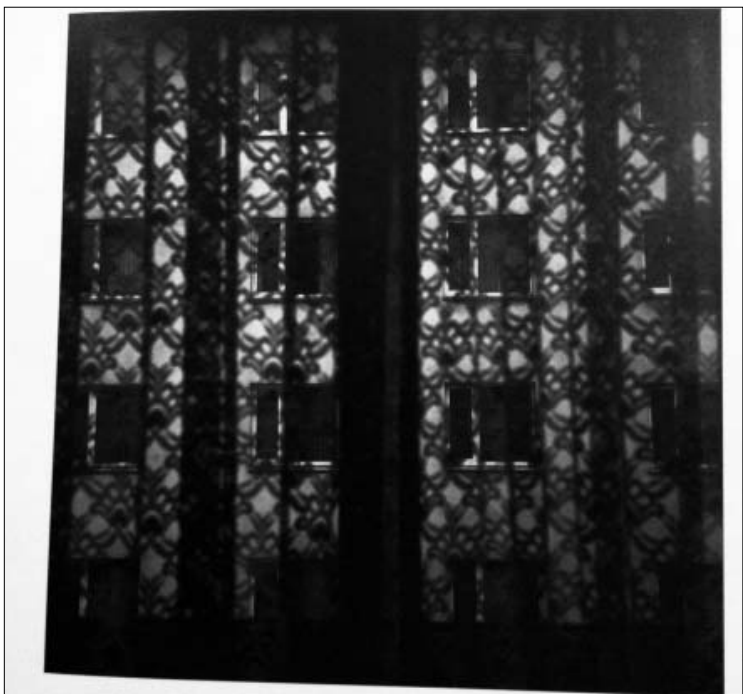

non-linear, non-narrative and repetitive. While looking at the pictures, the viewer notices that they frequently repeat, but always differ from one another by some minor details or shifts in framing [Fig. 9-10]. This recognition makes us go back and forth in the book in order to compare the images, which also enhances our haptic experience. These strategies have several implications. First, the cultural level is visualized in what we are used to perceiving as archival: the black-and-white images, juxtaposed with contemporary colour pictures, connote documentary traces of a bygone past.[37] Second, the fact that it is an archive of material objects, experienced tactually, suggests that we can dispose of

Fig. 8 [colour] them and construct their order and narrative - as the author does. An archive is also produced in the individual viewer's memory during the process of viewing and comparing the photographs. It is thus not a traditionally understood archive characterized by linearity and continuity, and controlled institutionally - it is guided by synchrony and experienced individually. Combining old and new photographs, Clement also visualizes a more general dimension of photography: in the act of

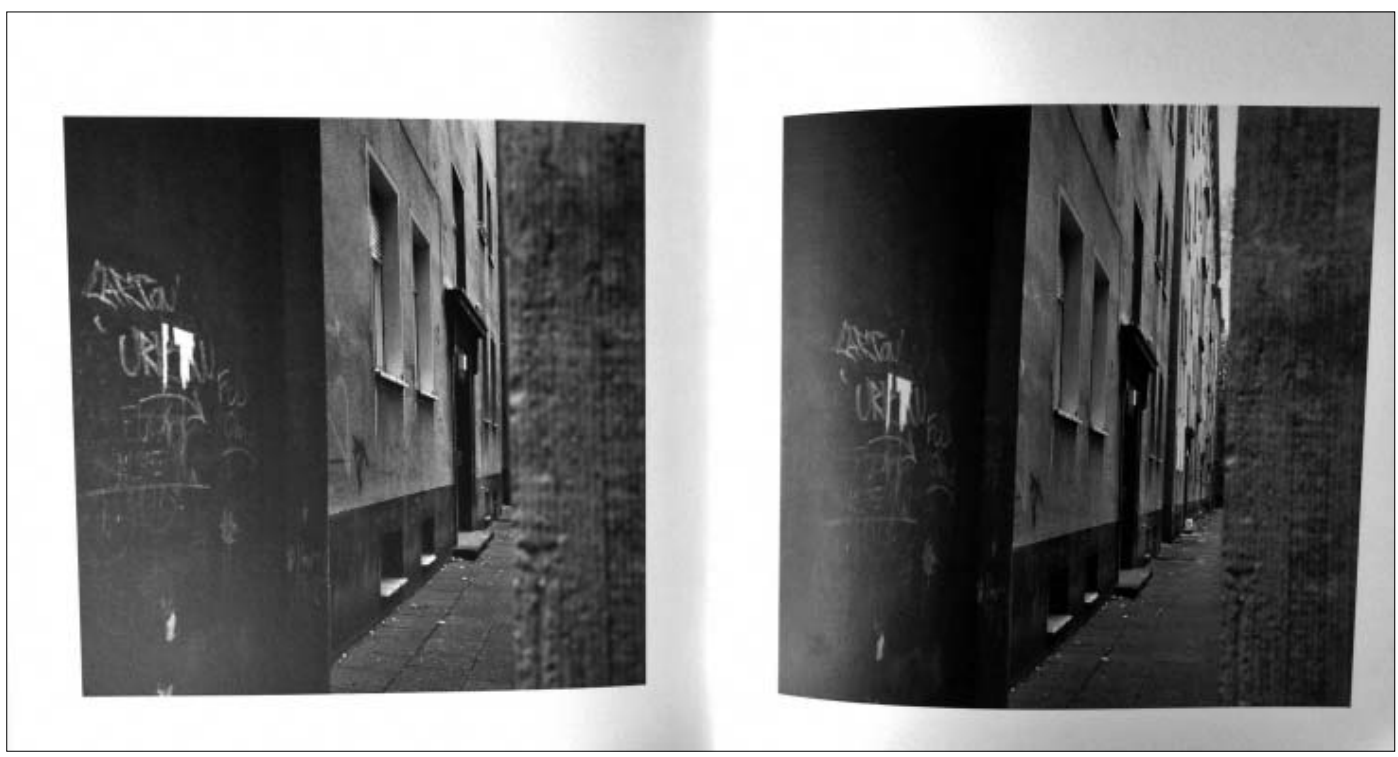

Fig. 9-10

[37] Black-and-white photography also denotes art photography. Clement evokes this convention with a picture on page 80. At the same time, this colour image depicting a hand holding a black-and-white old photograph points directly to the haptic experience of photographic objects. 
viewing, the past gaze of the photographer meets our present gaze. But this meeting is never complete: "The gazes of two beholders looking at the same picture diverge where memory separates them." [38] Thus, the grid epitomizes a filter of memory-images, stored in the memory of the camera and constituting both a cultural and individual archive.[39]

Encouraging the viewer to be-hold colour images through the grid of black-and-white and the other way round, the book has important implications concerning the "world beyond the frame", as Rosalind Krauss put it. In a large, black-and-white picture unfolding on two pages, we see a street name sign at the "U.[bahn] Pankow" subway exit [Fig. 11]. The street to which the steps lead is called "Otto-Grotewohl-Str." For

\section{The past of the future or the post- GDR condition photographed}

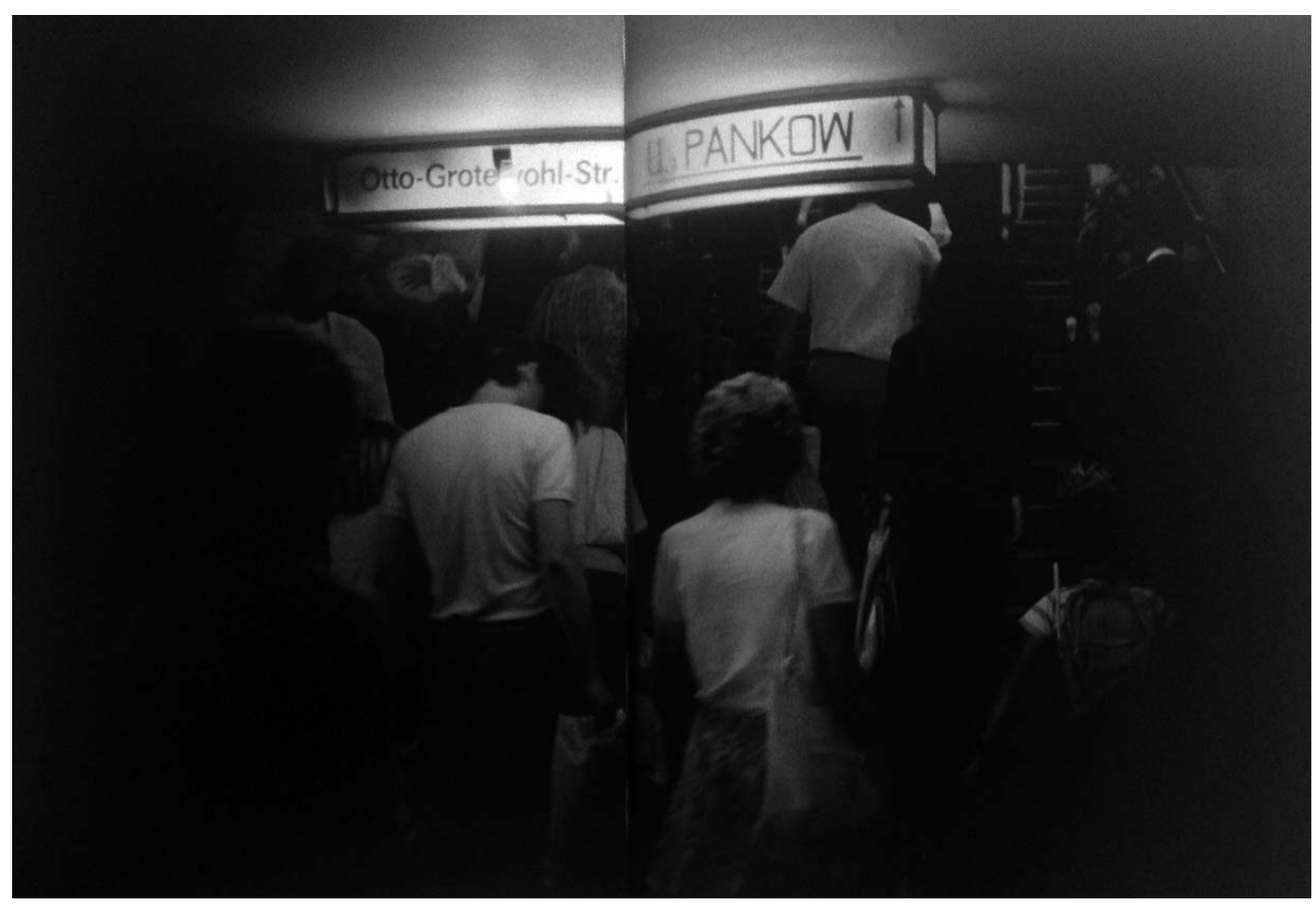

Fig. 11

[38] Belting, op. cit., p. 148. This is described by Belting as follows: "The symbolic act of perception in front of a photograph consists in an exchange of gazes. We recall the gaze, which is in turn recalled in the photograph. In this sense, photography is a medium between two gazes, and a part of this mediality consists in the time that lies between the recorded and the recognizing gaze", Belting, op. cit., p. 154. [39] Bergson describes memory-images as "mental photography" (p. 87) and "repetitions" retained and set out by our memory, leading to recognitions (pp.
89-90). But whereas images in general belong to a universe where everything repeats itself, photographs are distinguished by the aura of the unrepeatable time (Belting, op. cit., pp. 146-48). Moreover, our memories are not exact - they change over time and are not 'stored' forever and unchanged in our brains. This feature of memory is illustrated in Clement's book by minor shifts each time an image 'repeats' itself. Thus, Clement does not treat memory-images as 'frozen', like photographic images, but as changing over time, impossible to be repeated exactly. 
a viewer not familiar with Berlin and the history of the GDR, it might seem strange that, when trying to locate the street on the city map, there is nothing to be found under this name. Such 'revolving doors' opening up to reality - signs with street names and other markers of location encouraging the viewer to find the places on the map - are numerous in the book. In this particular case, the street - or rather, its name does not exist anymore. Having discovered this, the viewer becomes aware of the practices of renaming streets and places known from many post-communist countries, described by Huyssen as "the politics of willful forgetting".[40] Huyssen despises the phenomenon as "not just tinkering with the communist city text", but also "a strategy of power and humiliation, a final burst of Cold War ideology, pursued via a politics of signs." [41] Reviving no longer existing signs registered by his camera

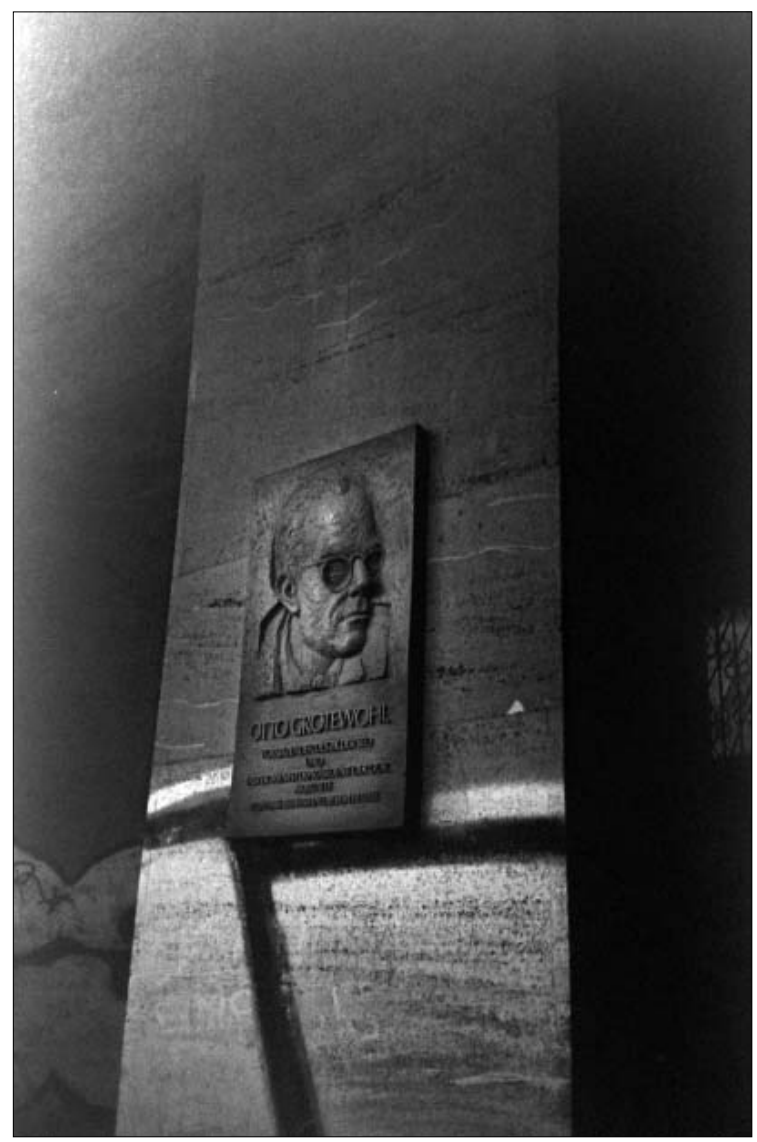

many years ago, Clement uncovers correlations between remembering, repressing and (not always willful) forgetting of the past. In the context of the book, the Otto-Grotewohl-Str. picture represents the GDR as an absence in the present city text a void, to use Huyssen's word.[42]

Even if we did not know who Otto Grotewohl was, we might have learned from the book before reaching this photograph. A few pages earlier, a colour photograph depicts a sunlit, well-preserved stone plate hanging on a wall of a building, informing that Otto Grotewohl, "Erster Ministerpräsident der DDR” [First Prime Minister of the GDR], lived and worked here (p. 78) [Fig. 12]. We might also recognize his portrait from another colour photograph placed even earlier in the book (p. 70) [Fig. 13]. This picture, however, shot sharply from below so that the diagonal axes are emphasized, reveals the surface of a dilapidated ceiling above the relief. Grotewohl's eyes, epitomized by his protuberant glasses, are 'looking' up towards the right edge. With this picture, we have no doubt that we are seeing the remnants Fig. 12 [colour] of a bygone past, a ghost-monument. Thus, reaching the black-andwhite picture of the Ubahn Pankow (pages 116-17), the viewer might experience a recognition, becoming at the same time conscious of the real erasure of traces of the past.

[41] Ibid., p. 54. 


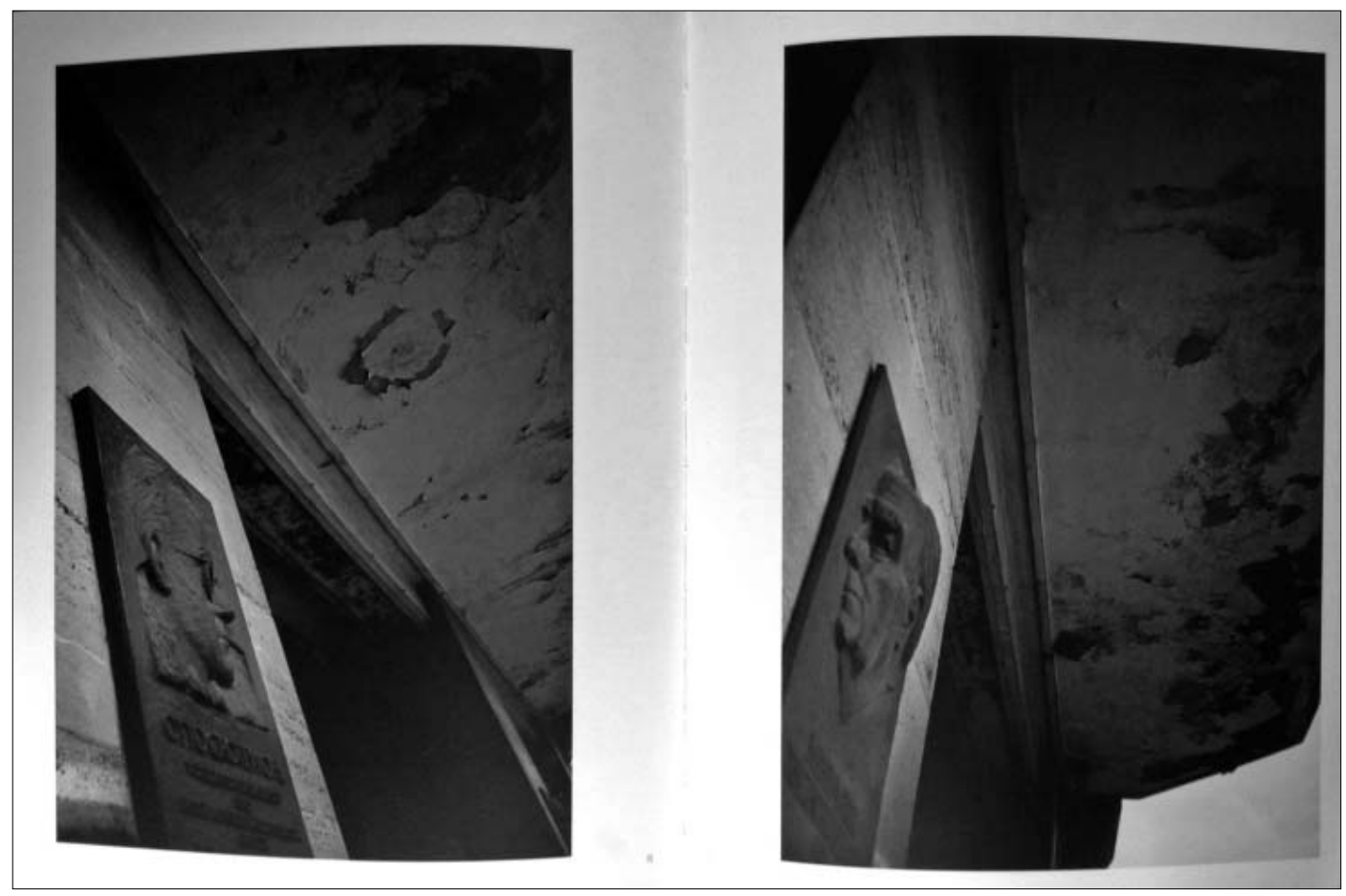

Fig. 13 [colour], 14 [colour]

But there are further implications coded in the colour photographs of the politician's decaying monument. As Huyssen reminds us, monuments are always inscribed in an ideological discourse, a means of legitimating power.[43] With these images, Clement presents communist ideology as deformed and corroding, as ruins, but ruins nevertheless lasting into the present. Even if repressed from the official city text, they can be found in its peripheries - and in images.

The order of the pictures showing the "Otto Grotewohl" signs follows from the most recent to the older. But the temporal structures produced in the book are more complicated than a mere reversal in chronology. It is impossible to view the low-angle frame of Otto Grotewohl relief outside the context of the neighbouring photograph, depicting an analogous bust of another GDR politician [Fig. 14]. The composition is similar, but with significant differences: the portrayed man is 'looking' in the opposite direction than Grotewohl, and the diagonal axis organizing the composition contradicts the axis in the picture of Grotewohl. In other words, the second picture annuls the movement forward, implied in the "First Prime Minister of the GDR" photograph. The movement 'towards the future' is reversed in a U-turnlike move, which is reinforced by the right-to-left, 'backward' direction organizing the composition. 

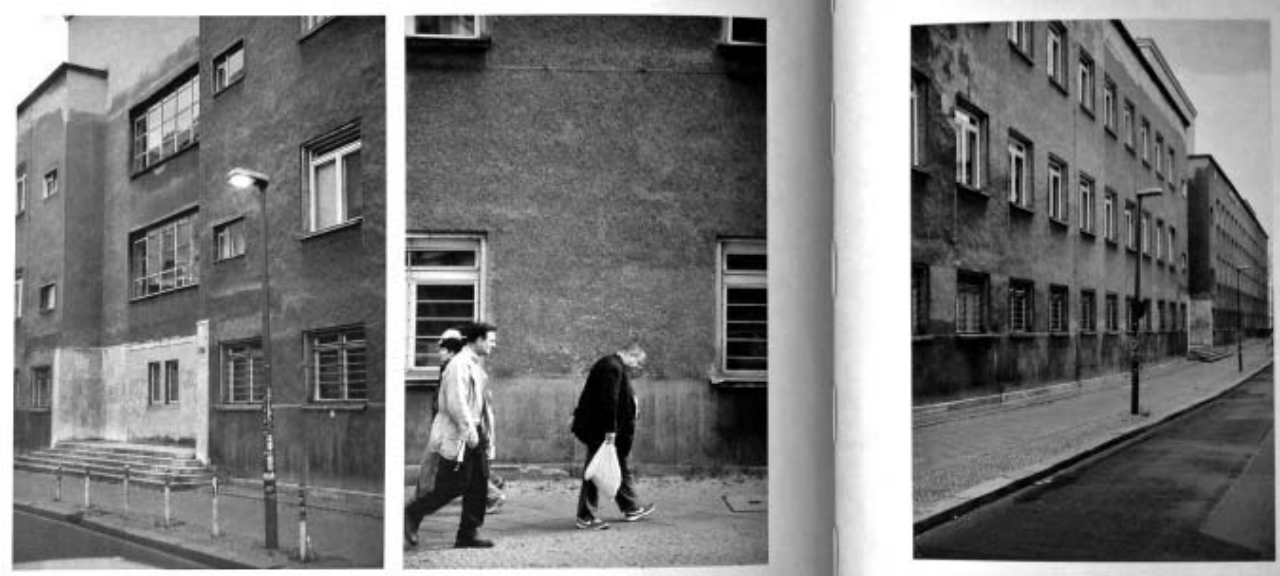

Fig. 15 [colour]

A similar 'freezing' of the time flow can be noticed in depictions of ordinary people and anonymous neighbourhoods. In the visual prologue of the book, we see three photos arranged horizontally in a grid-like composition [Fig. 15]. Now, the direction of the induced movement follows that of the book's reading - left-to-right: from the past (the path 'left behind' by the walking men), through presence (the walking men) and towards the future (the street unfolding 'in front of' the pedestrians). Several aspects of this two-page composition are striking: even though they suggest movement, discontinuity is created because we see three separate pictures. In consequence, both the spatial and temporal flows are chopped, just as photography "chops" time and space. Additionally, the fact that in the picture to the left the street lantern is turned on, whereas in the picture to the right the lamps remain unlit, introduces confusion regarding chronology: is the lantern still lit (because it is early morning) or is it already lit (because it is early evening)? The linearity of the narration and the flow of movement are therefore revealed as having been constructed by the photographer. Moreover, an element seems to be missing here: a fourth picture. Instead, the surface of the page is left white - a spatial and temporal void.

Thus, the future remains beyond the universe of Clement's book. Whenever a composition unfolds left-to-right, i.e. forward, the framing does not allow any broader, open view. This rule has no exception. Let 
us again take a look at the pictures of the stone plates commemorating the two GDR politicians [see Fig. 13-14]. A slight shift of framing in the second image opens up the space. But what it opens to is almost the equivalent of the white void of the page - a tiny fragment of a clouded sky, suspended above history and turned strangely upside-down, squeezed in the bottom corner of the frame.

The non-visualized and never reachable, although implicated, 'future' can be read as the future of the past - or, of the communist dream. As the American historian Timothy Snyder has put it,

the assumption among many who believed in the promise of communism was that the future was as real as if not more real than the present. Soviet propaganda was not a version of the world in which we live but rather a representation of the world to come.[44]

Thus, Clement stages the post-GDR condition as the past of the future, and shows the present as frozen and static. This impression is reinforced by his focus on old-fashioned looking, solitary people who seem out of time and unable to move forward. It is striking that, unlike in the black-and-white pictures, in the contemporary photographs people appear small, anonymous and passively subjected to their surroundings. Among the first pages of the book, a man with a far-from-modern look is walking on Oststraße towards the right edge of the frame, forward [Fig. 16]. The sign with the street name is tiny, but clearly visible. A very similar picture at the end of the book shows us the same man, walking back along the same path on Oststraße, towards the left frame of the picture, as if he was returning, performing a 'U-turn', or - stuck in the same place [Fig. 17].

As Huyssen stated in 2003, "Berlin as text remains first and foremost historical text, marked as much [...] by absences as by the visible presence of its past." [45] Krass Clement focuses both on the visible traces and absences of the past. A trace as such denotes something no longer existing. And yet, something else exists here - a universe pending strangely in a time gap. Bemoaning the mentioned "politics of willful forgetting" in the years following the fall of the Wall, Huyssen noted: "Forgetting is equally privileged in an official ad campaign of 1996, literally written all over the city: BERLIN WIRD - BERLIN BECOMES. But 'becomes what'? Instead of a proper object, we get a verbal void." [46] Whereas Huyssen sees Berlin as a spatial void, Clement's book - by means of its grid-like performance - creates a temporal void. In both cases, the void signifies a (post)ideological vacuum. Undoubtedly, the Danish photographer offers a very different vision of the German capital city than the one of which Huyssen wrote: "obsessed with architectural and planning issues, $[\ldots]$ in the midst of a government- and corporation-run building boom of truly monumental proportions." [47] Clement's Berlin

[44] http://www.nybooks.com/blogs/nyrblog/2014/ mar/o7/crimea-putin-vs-reality/ (accessed: January, $1,2015)$
[45] Huyssen, op. cit., p. 52.

[46] Ibid., p. 54.

[47] Ibid., p. 52. 

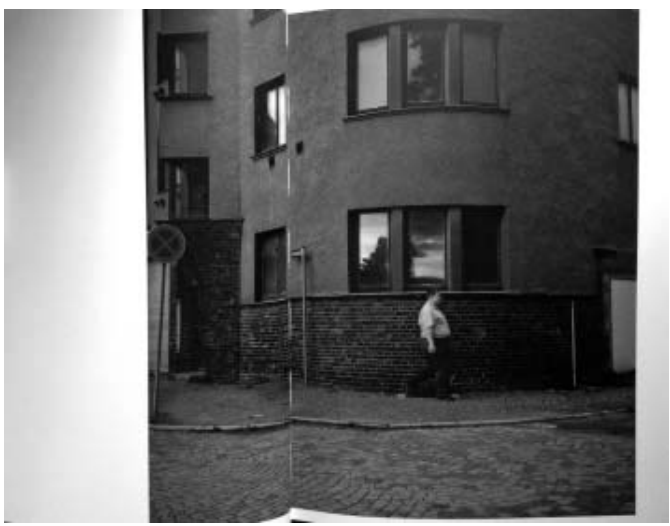

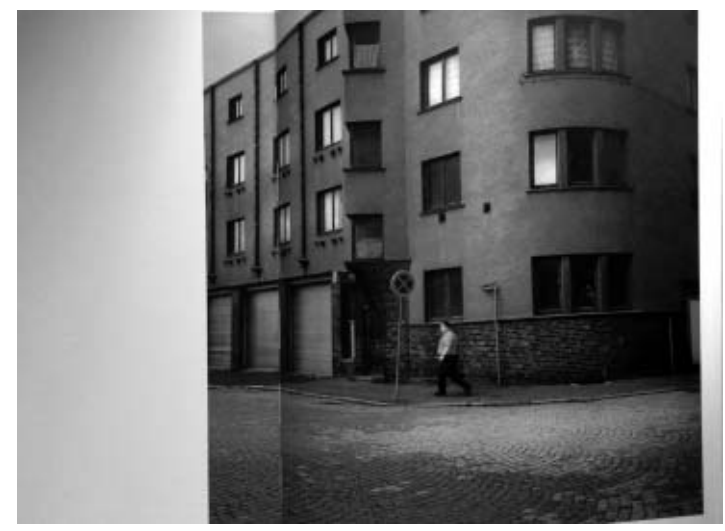

Fig. 16 [colour], 17 [colour] remains far from the monumental ultramodern metropolis of the future, promoted in official discourse. It differs equally from the Berlin known as a popular destination for 'alternative' pilgrimages by younger generations of tourists and international settlers, related to a trend described by Huyssen as "a strange mix of an originally leftist Kiez romanticism and a nineteenth-century vision of the neighborhood divided into small parcels." [48] Clement shows us another Berlin, partly forgotten, partly repressed and misremembered, but undoubtedly existing.[49]

The multilayered strategy of the grid - understood as both a formal rule guiding the book and a metaphor for the way we perceive and remember things - denotes a repetition, an impasse, temporal and spatial entrapment. Is Berlin a city trapped in "yesterday"? Or is the photographer's eye trapped in the past? Instead of being given answers, the viewer, whose "hand [is] working in partnership with the eye",[50] is stimulated to reflect on the relation between photography, (her own) memory, and perception. As if to meet Huyssen's regrets, the book focuses on Berlin's "communist city text" and its persistence in non-spectacular, marginal places. Is it a way of remembering or forgetting the GDR? The French philosopher Paul Ricoeur discusses forgetting from three perspectives: as an effacing of traces; as a persistence of traces; and as recollection.[51] Each of these stresses the inseparability of remembering and forgetting, which according to Ricoeur both support and undermine each other. Clement's book seems closest to the second approach, linking forgetting with the unrecognized persistence of traces, or images. Ricoeur writes: "If a memory returns, this is because I had lost it; but if, despite everything, I recover it and recognize it, this is
[48] Ibid., p. 61. Original emphasis. 'Kiez' is an "affectionate" German term for neighbourhood.

[49] Michałowska distinguishes between two approaches within documentary urban photography: one celebrating the future and showing the success of urban development, the other documenting traces of decay and destruction. See Michałowska, op. cit., p. 345. Clement's book remains beyond this binary division: it constructs a universe suspended in-between the past and the future, and the pictures do not romanticize the traces of the bygone world.

[50] Di Bello and Zamir, op. cit., p. 13.

[51] P. Ricoeur, Memory, History, Forgetting, trans. K. Blamey \& D. Pellauer, University of Chicago Press, Chicago \& London 2006, pp. 418-48. See also Michałowska, op. cit., p. 277. 
because its image had survived." [52] In the context of Clement's book, we are tempted to ask: Do memories survive in photographic images or do images create our memories?

The documentary dimension of the photographs in Venten $p a ̊$ $i$ går. Auf Gestern warten is undeniable. The question remains how they operate within larger narratives and relate to the processes of remembering/forgetting. With the grid as the organizing principle, the photobook constructs a complex narration in which old and recent pictures of (East) Berlin interact synchronically in ways problematizing the understanding of photography as a simple reference to reality and a medium able to rescue the past from oblivion. The viewer experiences the perception of the past as opaque. Encouraging reflection on the relationships between photography, memory, and reality, Clement suggests that "yesterday" can only be "waited for" behind the grid of the present. The photobook thus fosters photographic meta-reflection, emphasizing its self-containment and separation from the world, while at the same time it contributes to reflection on Berlin and Germany's post-GDR condition, subtly uncovering the mechanisms of forgetting, and reminding us that these "tiny pieces" of encapsulated time are "cropped from an infinitely larger fabric [...] of a world beyond the frame".[53]

The publication has been subsidized by the National Science Centre in Poland, no. DEC-2011/o3/D/HS2/00785. 